\title{
OBSERVATIONS ON A DEBRIS-COVERED POLAR GLACIER "WHISKY GLACIER", JAMES ROSS ISLAND, ANTARCTIC PENINSULA, ANTARCTICA
}

\author{
By T.J.H. Chinn and A. Dillon*
}

(Soil Conservation Group, Ministry of Works and Development,

Box 1479, Christchurch, New Zealand)

ABstract. "Whisky Glacier" on James Ross Island, Antarctic Peninsula, comprises a névé and clean ice trunk surrounded by an extensive area of debris-covered ice resembling a rock glacier. The debris-free trunk of the glacier abuts abruptly against the broad, totally debriscovered tongue at a number of concentric zones where debris-laden beds crop out at the surface in a manner similar to the "inner moraine" formations of many polar glaciers.

Ice structures and foliation suggest that "Whisky Glacier" is a polythermal glacier which is wet-based under the debris-free zone, and dry-based under the debriscovered zone. It is surmised that the glacier sole crosses the freezing front close to where the basal debris beds are upwarped towards the surface. Here, basal water is confined, and freezes to the under side of the glacier in thick beds of regelation ice which are uplifted to the surface along with the debris-laden beds. Ablation losses effectively cease beneath the blanket of debris covering the tongue.

The transition from wet-based to dry-based conditions at the glacier sole is a powerful mechanism for entraining debris into a glacier and, in the case of "Whisky Glacier", for lifting debris to the surface. It is suggested that this may be a mechanism for forming some polar rock glaciers.

\section{INTRODUCTION}

This paper discusses the structure of a polar glacier wherein debris-laden beds reach the surface to generate an exceptionally large area of debris-covered ice. The study was initiated by a fortuitous stream-burst, which cleared debris from a channel through a stretch of the debriscovered ice, permitting a study of its structure.

On our visit to Brandy Bay, James Ross Island, with an Instituto Antártico Argentino geological party, we studied glacier No. IJR.45 of Rabassa and others (1982) located at lat. $64^{\circ} 00^{\prime} \mathrm{S}$., long. $58^{\circ} 00^{\prime} \mathrm{E}$. (Fig. 1), informally called "Whisky Glacier" by the party.

James Ross Island, to the east of the northern tip of the Antarctic Peninsula, is almost completely covered by a single ice cap with the central dome reaching $1600 \mathrm{~m}$ (Aristarain and Delmas, 1981). The island consists of a plinth of poorly indurated Cretaceous sediments overlain by a great thickness of mid-Miocene volcanic rocks (Bibby, 1966). The unconformity between these two rock types varies considerably in altitude. The ice cap lies on top of the volcanic flows, while the marginal outlet glaciers have eroded deeply into the soft Cretaceous rocks to form a margin deeply crenulated by cirque-like forms. Ice drains over the arcuate cliffs in ice falls to reconstitute as outlet glaciers close to present sea-level.

The glacial geology of the Brandy Bay area has been described by Rabassa (1982), who identified six units of

Present address: Museo de La Plata, Catedra de Geomorfología, 1900 La Plata, Argentina.

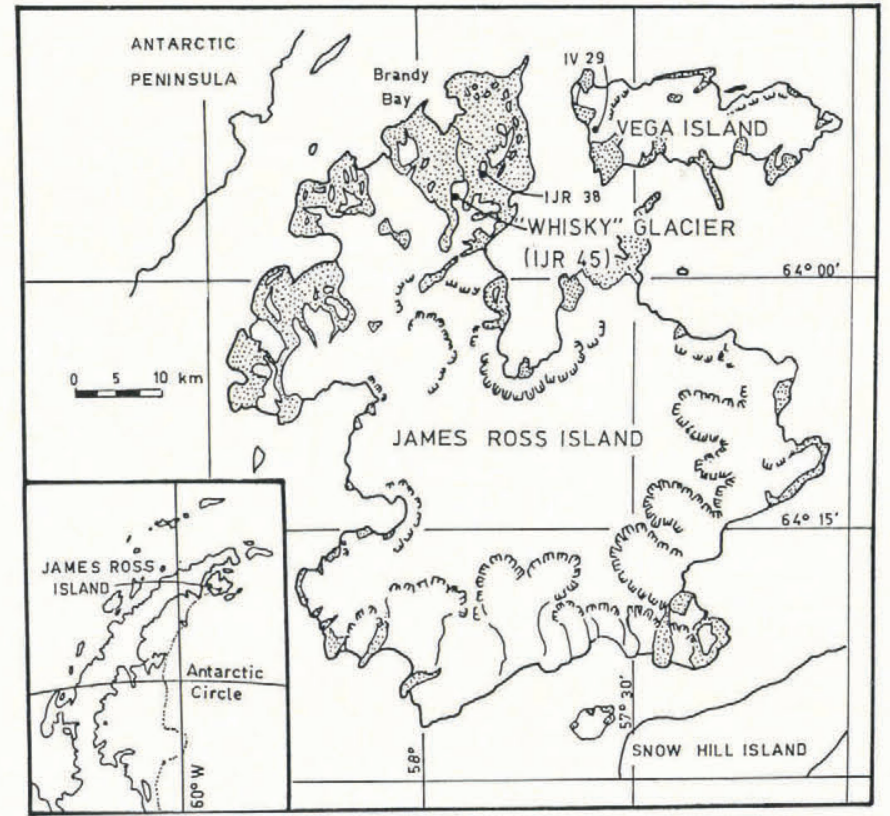

Fig. 1. "Whisky Glacier", location map.

glacial deposits ranging in age from Wisconsinan to present. His youngest unit includes the debris cover on "Whisky Glacier".

Westerly winds prevailing over the northern Antarctic Peninsula introduce a precipitation shadow to the east of the mountain chain, where the majority of the snowfalls are from southerly winds of passing cyclones. "Whisky Glacier" is located in the north-west of the island where the precipitation shadows from both wind directions leave the largest ice-free areas.

\section{"WHISKY GLACIER"}

"Whisky Glacier" comprises two distinct areas separated at a sharply defined boundary (Fig. 2). The upper névé is fed primarily by snowfall at a saddle to the south-east, where flow is north-westward under steep headwalls into the cirque of "Whisky Glacier". The summer snow line lies more than half-way down the gently sloping trunk. Below the snow line is an ablation area of clean, stratified, debris-free ice, approximately $1.5 \mathrm{~km}$ long by $1 \mathrm{~km}$ wide with numerous melt-water streams which join to discharge as a single stream. At the lower margin of the debris-free ablation zone, the glacier changes abruptly into a broad lobe of completely debris-covered ice up to $1.5 \mathrm{~km}$ in width and $1 \mathrm{~km}$ in length (Fig. 3). This transformation occurs where a series of concentric debris-rich ice beds crop out at the glacier surface. 


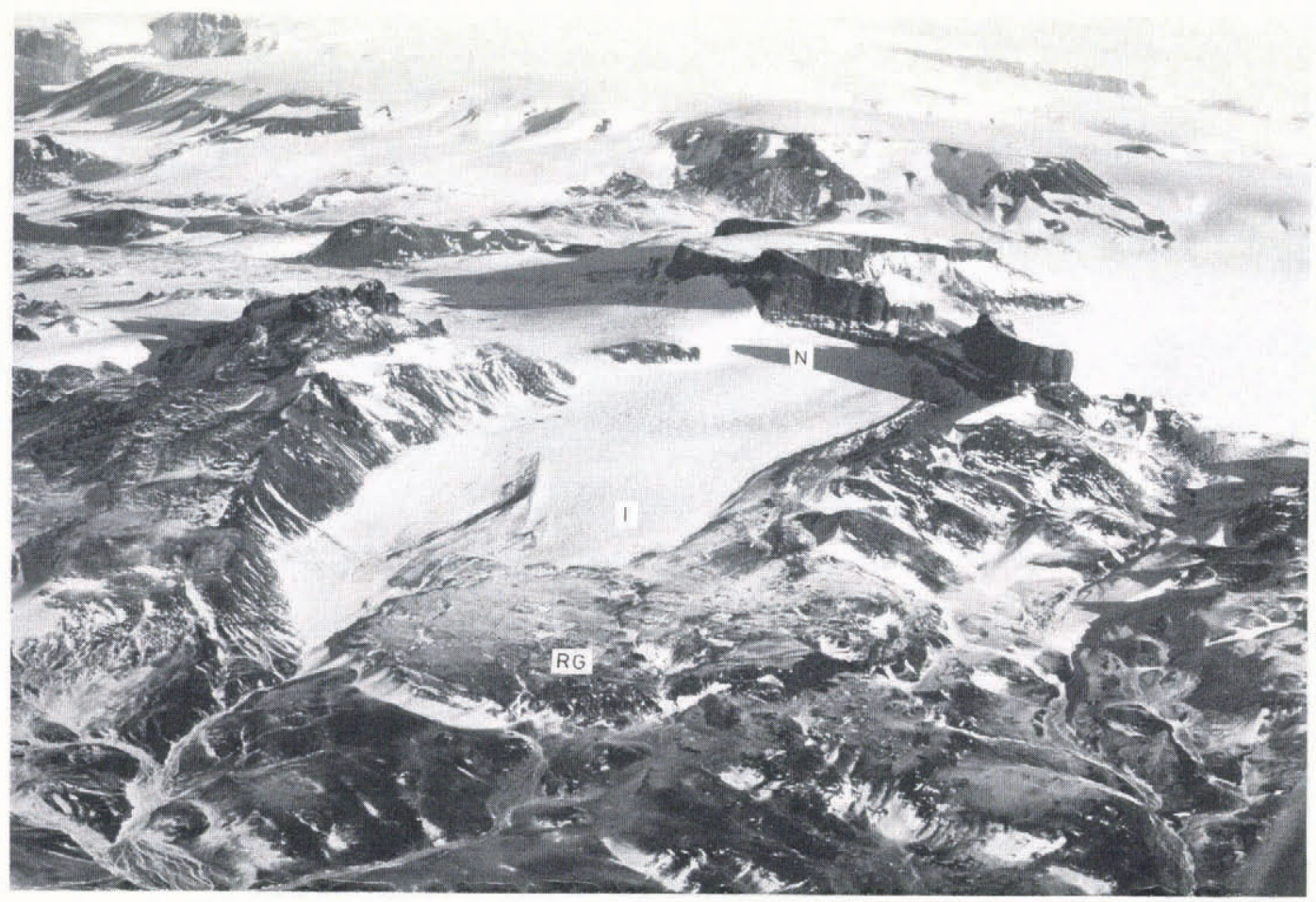

Fig. 2. "Whisky Glacier", aerial view southward after a recent snowfall. RG, rock-glacier tongue; I. debris-free ice; $N$, névé area.

\section{Debris-laden beds}

The most striking feature of "Whisky Glacier" is the abrupt boundary between clean white ice and a thick debris cover at a set of ridges where debris-rich beds dip steeply into the glacier. About ten parallel but discontinuous concentric ridges occur over a distance of $200 \mathrm{~m}$. The uppermost of these debris beds appear on the clean ice as thin debris bands associated with about $10-20 \mathrm{~cm}$ of vertical displacement similar to reverse faults. Within a short distance down-stream, these give way to debris-covered ridges up to $5 \mathrm{~m} \mathrm{high}$, all showing fractures on the crests indicating present activity. This debris shows little weathering, and signs of facturing at the ridge crests continue to the lowest ridge crest mapped in Figure 3. At two sites, cross-sections through the ridges were exposed.

\section{Blue-ice beds}

Associated with the beds of debris-laden ice are beds of clear bubble-free ice of a striking blue colour. In hollows and amongst moraine cover this ice presents a smooth, clear, blue-black surface allowing visibility to some meters into the bubble-free interior, while steeper faces and pinnacles appear bright blue. With decay of the crystal boundaries by radiation, the ice fractures into large white crystals $50-100 \mathrm{~mm}$ in diameter. These blue-ice beds are lensoid along their strike, and up to tens of meters thick where visible at the stream section.

\section{Debris-covered area}

Below the concentric ridges of the debris beds, the glacier continues as a wide, thickly debris-covered tongue, with virtually no exposures to indicate that it is underlain by ice. The surface is furrowed and undulating to almost flat, with the larger boulders up to $6 \mathrm{~m}$ in diameter sitting on, rather than embedded in, the debris cover. There are few of the structural and ablation relief features frequently associated with marginal ice-cored moraines of polar glaciers. The most prominent longitudinal features are inactive stream channels. Two large thermokarst depressions occur near the western margin. Where not obscured by a snow-and-ice apron, the $25 \mathrm{~m}$ high glacier front (Fig. 2) is a steep, loose scree. The generally steep shape, unstable nature, and absence of well-developed stream channels at the toe of the slope, suggest that the front may be advancing.

Beyond the frontal margin of the glacier, the gently undulating topography contains no obvious moraine ridges to indicate the positions of any relatively young (Holocene) advances of "Whisky Glacier". The area is, however, veneered by till and supports low, broad subdued moraines. A concentration of particularly large boulders on "Whisky Glacier" has an intriguing continuation beyond the glacier in a linear distribution north-westward to the coastline.

\section{Ablation}

Ablation on the upper glacier surface was predominantly by melt, which drains from the white ice and through areas of thinner moraine cover, before descending as a single stream into a $5-10 \mathrm{~m}$ deep channel incised into the ice (Fig. 3). The stream descends beneath a snow bridge into a subglacial channel to emerge from beneath an ice apron at the glacier margin.

This single stream draining the glacier, informally named "Rio Ginebra" by the party, flowed continuously during the visit, even when covered by ice and snow, and surface melt had ceased after cold southerly blizzards. Apart from "Rio Ginebra" and the one channel surveyed, no other melt-water streams were seen on the rock-glacier surface, and negligible melt fed a few seeps seen flowing from the glacier margin.

\section{FIELD MEASUREMENTS}

The study was carried out towards the end of summer when stream flows were rapidly diminishing and the thawed active layer of the ground was refreezing. Temperatures ranged between about $+10^{\circ}$ and $-10^{\circ} \mathrm{C}$, and a recent blizzard had left a partial covering of drifted snow throughout the area.

The party was fortunate to witness a sudden torrent of water which poured over the glacier front immediately behind the camp (Fig. 4). The initial debris-charged surge had an estimated flow of $5001 \mathrm{~s}^{-1}$, which, after several hours ebbed to a clear discharge of about $501 \mathrm{~s}^{-1}$. The stream was found to emerge from a group of springs about 


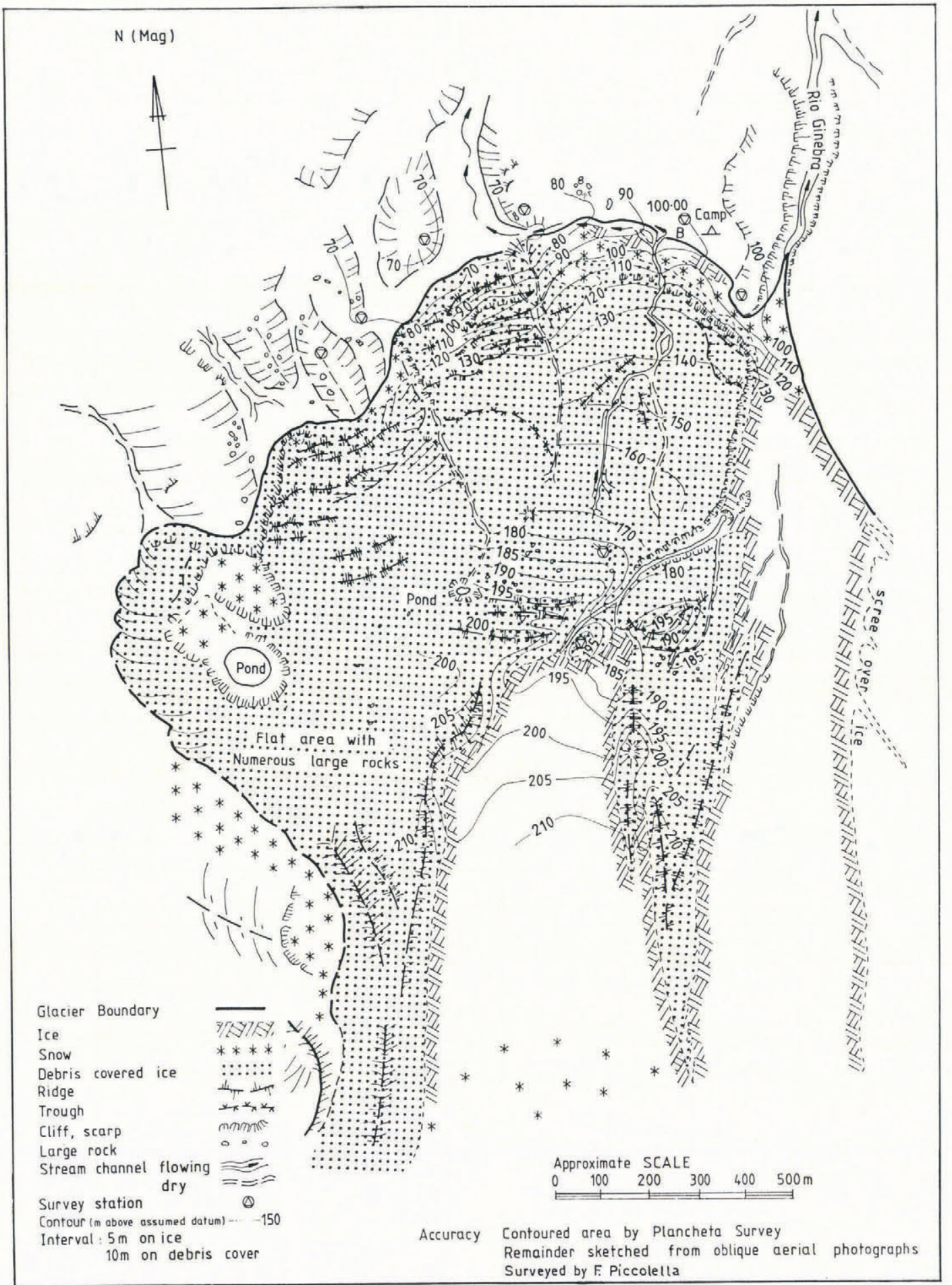

Fig. 3. Topographic sketch of "Whisky Glacier".

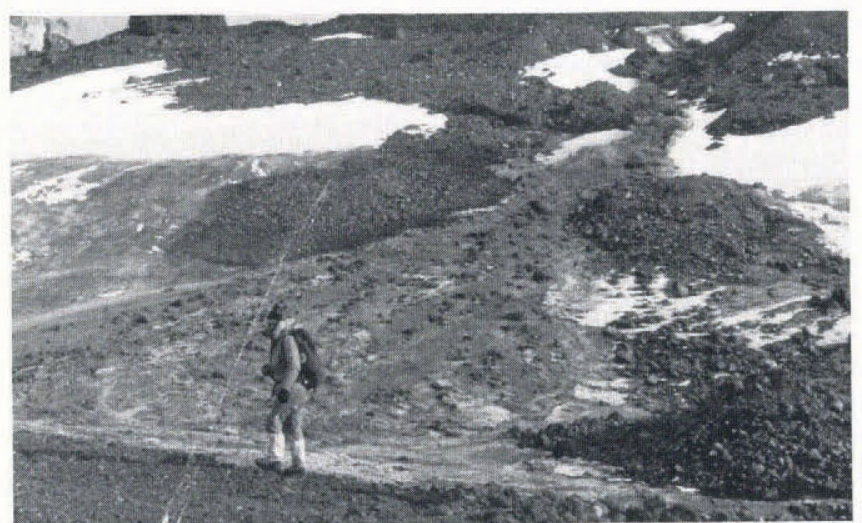

Fig. 4. The torrent discharging over the glacier front during the initial short period of high flow.
$600 \mathrm{~m}$ above the glacier margin. Presumably, the sudden appearance of water at the surface was caused by a change in the internal melt-water drainage system, or perhaps the appearance of basal melt water at the surface. The surface flow followed a pre-existing channel up to $2 \mathrm{~m}$ deep. Rock debris along most of the channel length had been removed to reveal both the ice structure and depth of the debris cover (Fig. 5).

The freshly exposed section was immediately surveyed and ice structures mapped. The exposure was only temporary and within a couple of days the rock cover had slumped to obscure almost all of the exposures. The course of the channel was mapped using a plancheta (optical alidade on a plane table) and staff, and the survey was continued through the debris ridges on to the debris-free ice of the ablation area.

Ice beneath the debris cover was clear and distinctly foliated and, although remarkably clean, contained occasional 


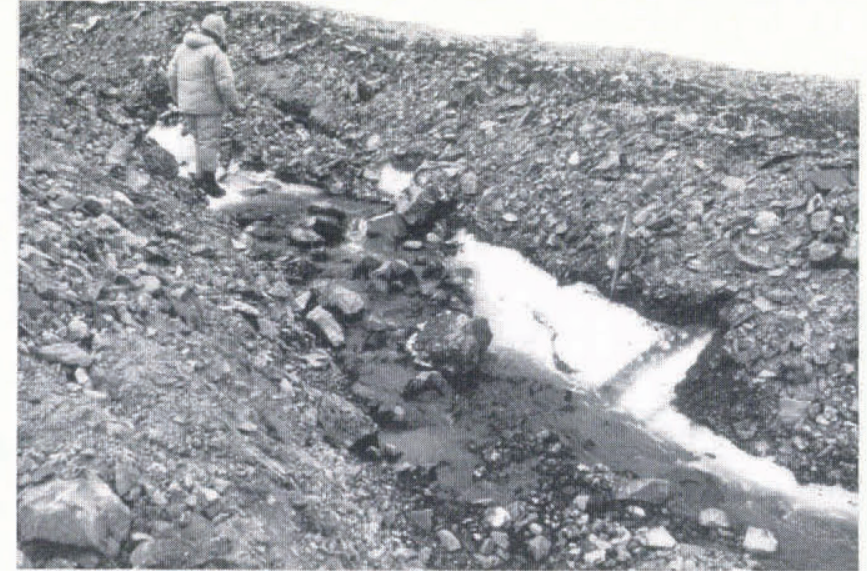

Fig. 5. Section of the recently cleared channel in the rock-glacier surface showing ice stratigraphy and thickness of debris cover. Ice-axe length is $80 \mathrm{~cm}$.

layers of debris. Attitudes of the ice folia were measured at frequent intervals, using a compass and inclinometer. Occasional bands of coarse crystals cutting obliquely to the general direction of foliation were encountered. A description of the ice features and nature of the debris cover at each point of measurement is given in Table I. The overburden consisted mainly of uniformly fine basalt gravels of angular "fanglomerate" texture, with some areas of pebbly

TABLE I. ICE STRATIGRAPHY ALONG THE FLOOD CHANNEL ON THE ROCK-GLACIER SECTION. LOCATION OF POINTS (PROGRESSING UP-STREAM) IS GIVEN BY THE DIP VALUES IN FIGURE 6

$85^{\circ} \quad$ Clear black ice with large crystals.

Cover of brown gravels over blue silty sand.

$85-68^{\circ} \quad$ Structureless massive ice, with thin horizontal silt bands.

Brown gravelly till.

$68^{\circ} \quad$ Horizontal debris band near ice top

Coarse brown till with no matrix.

$56^{\circ} \quad$ Banded ice of large and small crystals and debris.

Fanglomerate-type till.

$55^{\circ} \quad$ Banded ice with rare horizontal debris layers. Brown till with matrix.

$66^{\circ} \quad$ Coarse ice crystals.

Bouldery till with few fines, boulders to $5 \mathrm{~m}$ diameter.

$70^{\circ}$

Blue and white banded ice containing no debris.

Gravelly fanglomerate till.

$57^{\circ} \quad$ Clean section, banded ice.

Salt deposits under surface rocks.

$51^{\circ} \quad$ Banded ice containing ice of fine brown debris.

$64^{\circ} \quad$ White ice with clear bands.

$75^{\circ} \quad$ Numerous thin debris bands.

$64^{\circ} \quad$ Gravelly till over thinly foliated white ice.

$69^{\circ} \quad$ White ice with numerous blue and amber bands. sands and silts derived from the subglacial Cretaceous sediments. The lower margin of the glacier was defined by mapping between "Rio Ginebra" and the depressions containing a large pond (Fig. 3). The remaining areas mapped in Figure 3 were compiled from oblique aerial photographs.

\section{Surface debris cover}

The thickness of the debris cover was measured at a number of exposures and, from these measurements, it was calculated that the total cover amounts to about $1.25 \times 10^{6} \mathrm{~m}^{3}$.

The debris-covered zone showed an obvious down-glacier increase in age. The surfaces from the debris-band ridges up to the clean ice area were fresh in appearance with unweathered debris adjacent to the uncovered ice. Below the lowest ridges, the surface had an "old" appearance, with mosses on the leeward sides of boulders, and salt precipitates on the under sides of the clasts.

In an attempt to estimate the relative ages of the debris cover of "Whisky Glacier" and nearby moraines of Brandy Bay, weathering-rind thicknesses on surface basaltic clasts were measured by the method of Chinn (1981[b]). Measurements were made at a number of sites on "Whisky Glacier" and continued on the till-covered surface extending out from the glacier front. A sequence of arcuate moraines, not present at "Whisky Glacier", is preserved in front of a glacier across the valley opposite "Whisky Glacier", and these moraines were also sampled for rind thickness.

\section{Results}

"Whisky Glacier" has a form similar to the "inner moraine" structures of many polar glaciers which have been extensively studied (e.g. Ward, 1952; Swinzow, 1962; Souchez, 1967, 1971; Hooke, 1968, 1970, 1973[a]; Hooke and Hudleston, 1978) but has two unusual features not described elsewhere. The first is the extent of the zone of debriscovered ice, large enough to be considered a type of rock glacier, which is far greater in areal extent than the debriscovered ice areas described from other polar glaciers. The second unusual feature is the set of clear blue-ice beds which do not appear to have been described in the literature, although one of the authors has observed very similar beds at the margin of Wright Lower Glacier in the Dry Valleys region of Antarctica (Chinn and Maze, 1983).

The overall structure of the glacier (Fig. 6) is one of simple inward dipping foliae but with a change from synform structure to a uniformly steeply dipping structure, from the clean-ice area to the debris-covered area. The lower part of the clean-ice area is distinctly foliated with a simple synclinal structure, typical of uncomplicated glaciers where the foliation may be of sedimentary origin (Hooke and Hudleston, 1978). The dip of foliae steepens markedly towards both the lateral and terminal margins of the clean ice, commonly with dips reaching to between $70^{\circ}$ and $90^{\circ}$. No change in dip attitude between the clean and debriscovered ice was detected, suggesting that the debris-rich beds parallel the clean-ice foliation. The debris-covered section has a similar structure throughout, with dips between $60^{\circ}$ and $70^{\circ}$ (Fig. 6). This consistency in attitude indicates that the whole lower glacier flows uniformly with minimal distortion.

Down-glacier of the clean ice, the glacier's surface gradient increases from $3.5^{\circ}$ to $5^{\circ}$, implying an increase in basal shear stress under the debris-covered ice. Numerous measurements of attitudes of white-ice foliation and of the clear blue-ice beds were made across this junction. Sections through ridges containing debris-rich beds were seen at a number of sites (Figs 7 and 8), each exposure revealing a similar down-glacier sequence of beds:

White ice/stratified debris-rich ice/massive debris-rich ice/clear blue ice/white ice.

This sequence is repeated a number of times, suggesting that the sets of beds are periodically generated at the one position. As each set slowly flows down-glacier, it is replaced by a new set formed at the original up-glacier location. However, this sequence of beds was not recognized 


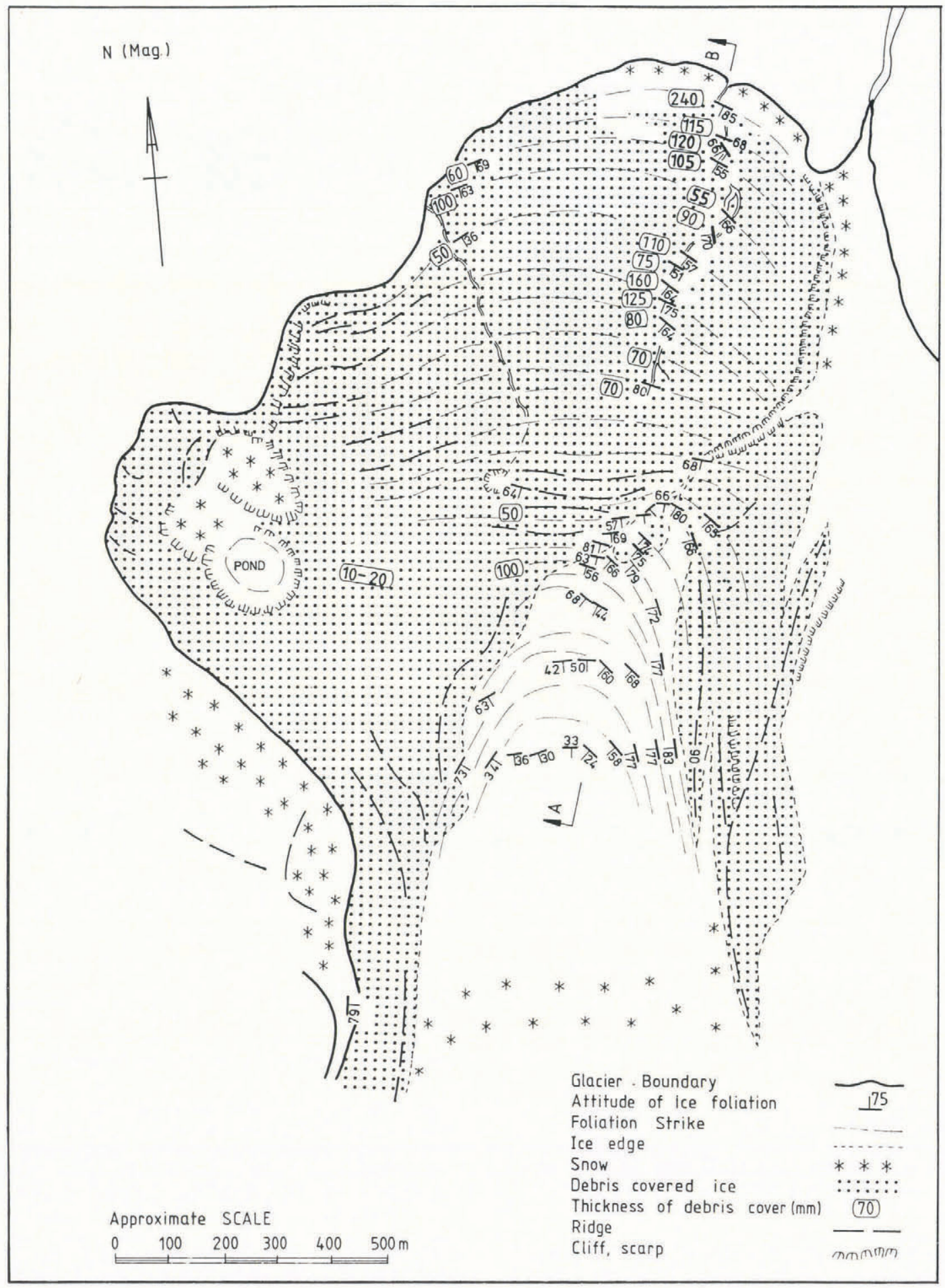

Fig. 6. Structural map of "Whisky Glacier".

in the channel exposures at the debris-covered zone. Each of the individual beds varied in thickness and extent, and clear blue-ice beds were not always present. The thickness of the debris beds varied from a few centimeters to 6 or $8 \mathrm{~m}$, and were composed of a massive lower (down-glacier) unit overlain by beds of highly foliated debris similar to those described from the Dry Valleys region (Shaw, 1977[b]). The massive basal unit also included scattered thin lenses of clear ice similar to those described by Shaw (1977[b]) and Souchez and Tison (1981).

The debris cover of Figure 7 suggests that the dominant vertical displacement movement occurs in an area between the white ice and the stratified debris-rich ice. At the surface above this contact there is a change in thickness of debris cover, together with a surface dislocation which could be traced along the up-stream side of the ridge. Also present was a change in colour from fresh grey debris upstream to brown oxidized debris down-stream of the fracture. This colour change is presumably from rapid oxidation of silts (Boulton, 1970).

\section{Ablation and run-off}

No ablation measurements were made during the comparatively short period of study. However, the early summer position of the toe of the ice apron near the camp could be determined from small melt-water channels and associated deposits of silt on the upper surfaces of the rocks. The distance these marks extended from the toe (up to $15 \mathrm{~m}$ ) and the inclination of the ice front $\left(18^{\circ}\right)$ allow an ablation loss for the summer to be estimated. The calculated summer ice loss, normal to the apron surface, was approximately $4.5 \mathrm{~m}$. This loss would presumably be a little 

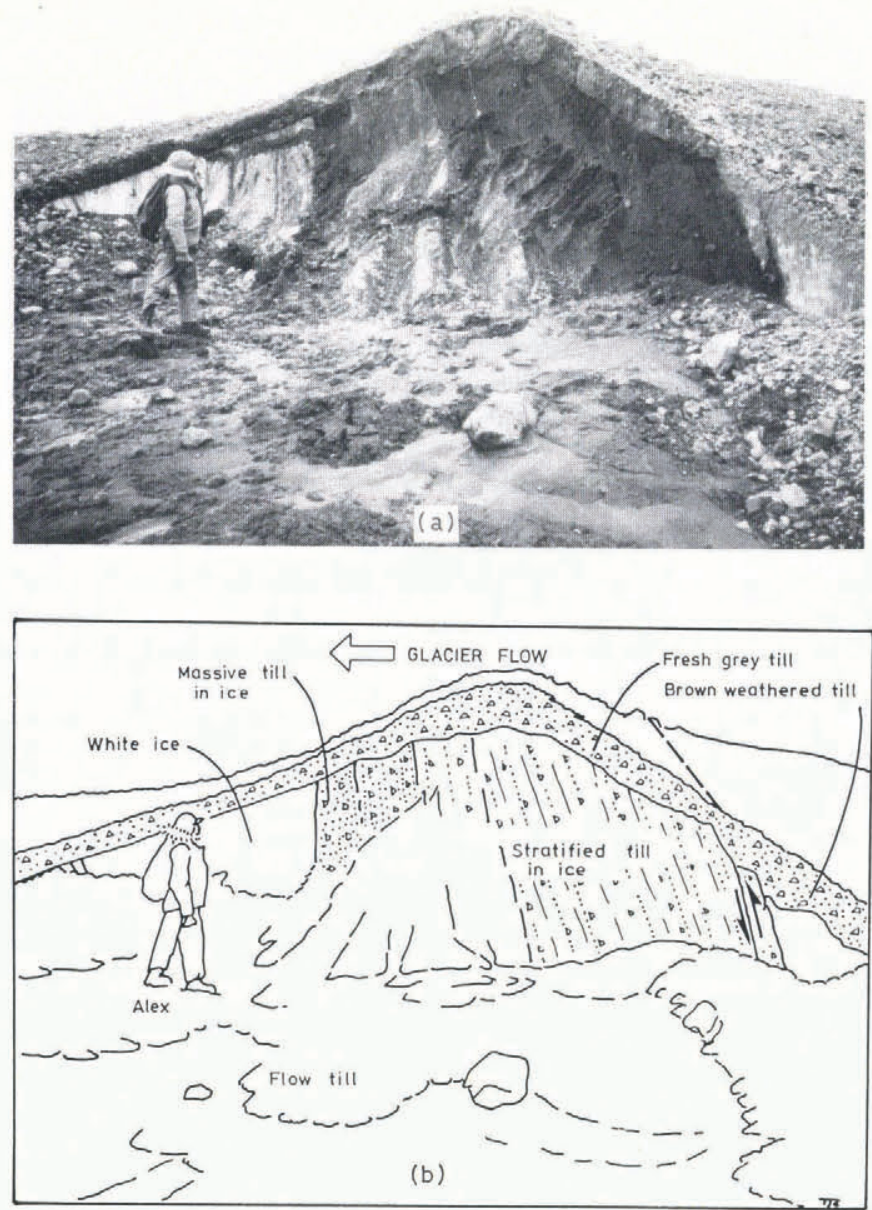

Fig. 7. Section of shear zone, west side of the glacier.

(a) Photograph, (b) Interpretative sketch showing different ice types.

more than that from the upper white ice of the clean glacier tongue, giving summer ablation loss here of perhaps $4 \mathrm{~m}$ of ice.

Elementary flow-discharge measurements were made on "Rio Ginebra" from timed floats with water-level readings. Discharges were computed by the method of Toebes (1963). The maximum estimated discharge was $17401 \mathrm{~s}^{-1}$ with estimated daily mean discharges ranging from 870 to $71 \mathrm{~s}^{-1}$.

From the meagre data gathered, a mean daily discharge of $\approx 1000 \mathrm{l} \mathrm{s}^{-1}$ was estimated for the entire summer melt period for the "Rio Ginebra". This gives a total seasonal loss by run-off from "Whisky Glacier" of $11 \times 10^{6} \mathrm{~m}^{3}$, about 3.4 times that discharged by Onyx River of the Dry Valleys region (Chinn, 1981[a]). This figure appears to be excessive as it gives a total summer ablation loss of $8.2 \mathrm{~m}$ water over the whole $1.3 \mathrm{~km}^{2}$ of both the "rock glacier" and bare-ice areas, and suggests that a large proportion of the melt-water run-off may also come from the bare-ice slope above the eastern side of the glacier.

This lateral ice slope joining the eastern side of the glacier lies in the position of an accumulation area feeding the lower eastern margin of the glacier (Fig. 3), but it currently has bare ice where a névé would be expected, indicating that this part of the glacier has had a strongly negative balance over the past few years.

\section{Relative ages of surfaces}

Weathering rinds of surface boulders show a wide scatter of thicknesses with few consistent modes (Fig. 9). The majority of the rocks had weathered joints, facturing, and exfoliation, and on the older deposits many were weathered through. Rocks of site 5 were older and more deeply weathered than those of site 4. Post-depositional fracturing is apparently responsible for the younger rind thicknesses made.
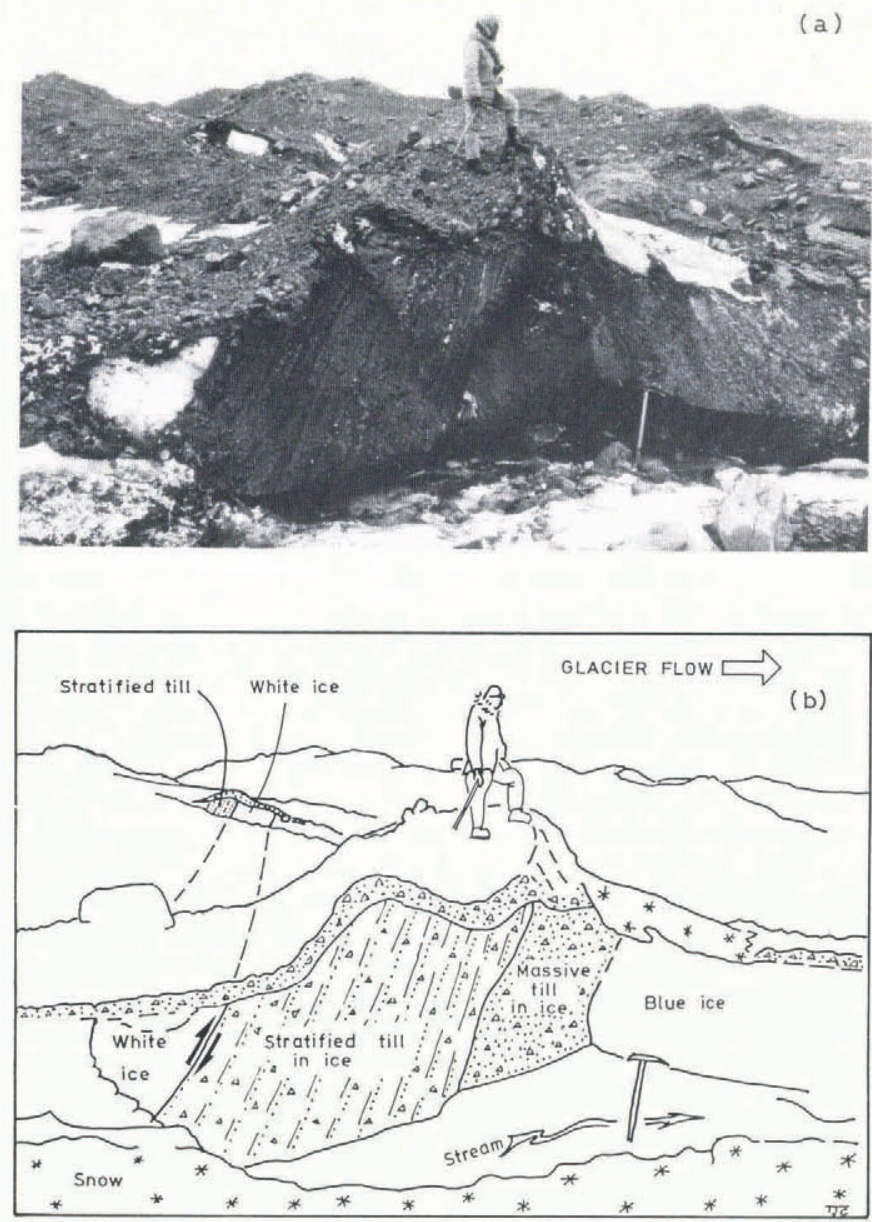

Fig. 8. Section of shear zone cut by the melt-water stream. (a) Photograph, (b) Interpretative sketch showing different ice types.

To estimate crudely the ages of the surfaces, the thicknesses were compared with those of Colman and Pierce (1981) for sub-surface basalts of western United States (Fig. 9). Although these results are for sub-surface rinds, Colman

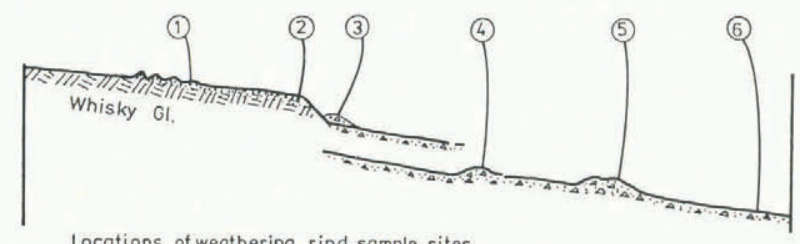

Locations of weathering rind sample sites

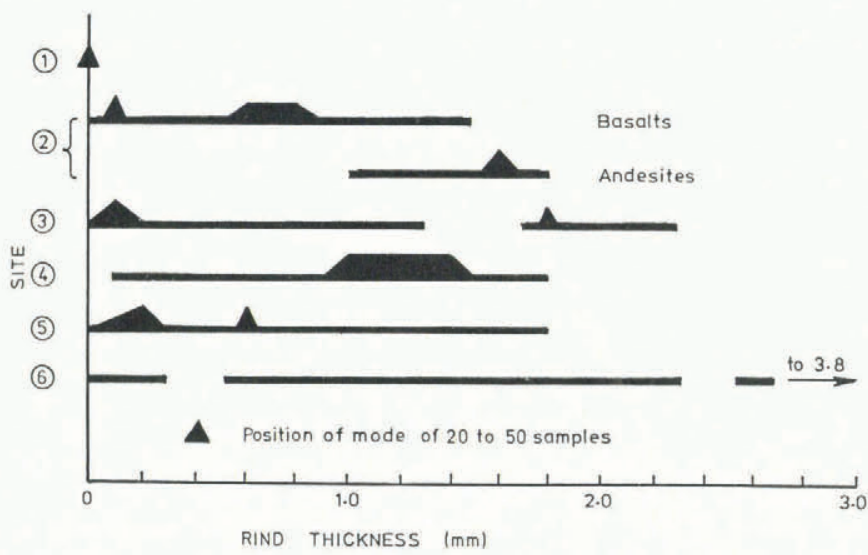

Fig. 9. Distributions of weathering-rind thicknesses on surface boulders of deposits on, and adjacent to, "Whisky Glacier". 
and Pierce $(1981$, p. 7) suggested that surface rinds are of similar thicknesses, but are less reliable. However, Chinn (1981[b]) found rinds on surface sandstones were around twice as thick as those for sub-surface clasts.

The weathering-rind growth rates given by Colman and Pierce indicate that thicknesses of $0.5-1.0 \mathrm{~mm}$ found in the Brandy Bay area are likely to be late Pleistocene rather than Holocene in age. Rind growth in Antarctica does not appear to be slower despite the much colder climate. The rind thicknesses (and degree of weathering) in the "Whisky Glacier" area imply that the bulk of the surfaces are older than Wisconsin, and that the lower debris-covered area of "Whisky Glacier" has been in existence since at least the beginning of the Holocene. For this to have occurred, the flow rate of the lower zone of "Whisky Glacier" must be in the order of only $0.1 \mathrm{~m} \mathrm{a}^{-1}$. The implication that the Brandy Bay area has remained ice-free throughout the Wisconsin is unexpected, and requires that further detailed investigations be made into weathering-rind growth rates in this area.

\section{DISCUSSION}

Apart from its wide zone of debris-covered ice, and beds of clear blue ice, the structure of "Whisky Glacier" closely resembles that of many margins of polar and subpolar glaciers, ice caps, and ice sheets. At the margins of these glaciers, beds of debris-rich ice are upwarped to the surface where they form linear supraglacial moraines or "inner moraines", parallel to the ice margin. Outward of these features, debris-covered ice occurs in variable widths from a few meters to a maximum of a few hundred meters and, in most cases, the inflection between the glacier margin and the ground is infilled with a wind-drifted wedge of snow or ice. "Whisky Glacier" has the clean-ice area, upwarped debris beds, and a wind-drifted snow wedge at its lower margin, but the two latter features are separated by $1 \mathrm{~km}$ of debris-covered ice or rock glacier.

\section{"Inner moraine" studies}

The origin of the debris forming "inner moraines" and the mechanisms of its transport to the surface have been the subject of many studies and considerable controversy over the past three decades. These marginal supraglacial moraine formations have been variously described as "inner moraines" (Weertman, 1961), "shear moraines" (Bishop, 1957) and, to avoid generic implications, "ice-cored" moraines (Souchez, 1971). Inner moraines have been extensively studied in Baffin Island (Goldthwait, 1951; Ward, 1952; Hooke, 1973[a], [b]; Hudleston, 1976), Thule in north Greenland (Bishop, 1957; Goldthwait, 1960; Swinzow, 1962; Hooke, 1970), Svalbard (Boulton, 1970), Ellesmere Island (Souchez, 1971), and Antarctica (Hollin and Cameron, 1961; Souchez, 1967). From their appearance, the inclined planes of debris-laden beds have been referred to as "thrust planes" or "shear planes", by one school of investigators (Goldthwait, 1951, 1960; Bishop, 1957; Souchez, 1967; Boulton, 1970; Hambrey, 1976), suggesting that debris is carried to the surface along discrete shear planes or reverse faults. Another school of investigators, following more theoretical approaches, have demonstrated that the occurrence of shear planes is not mechanically acceptable (Weertman, 1961; Hooke, 1968, 1973[b]; Hooke and Hudleston, 1978). Whichever mechanism occurs, it has been demonstrated that compressive flow and deformation occur in the vicinity of the margins of these glaciers (Hooke, 1970). Strain studies made in excavated tunnels (Hooke, 1973[a]; Baker, 1986) have shown that differential deformation, a form of shear, occurs in inter-layered clean ice and debris-rich ice beds, but fault-type displacement was not found in these studies. Although fault (shear-plane) displacement has not been found to occur within glaciers beneath inner moraines, this form of dislocation has been observed on polar glaciers, e.g. at the margin of Taylor Glacier (Shaw, 1977[a], fig. 7), at a glacier on Svalbard (Boulton, 1970, fig. 3b), and on the surface of Barnes Ice Cap (Ward, 1952, fig. 3).

Experiments by Hooke and others (1972) suggest that debris concentration in excess of $10 \%$ by volume stiffens ice rather than softens it, suggesting that the bulk of differential flow occurs in the inter-layered clean and debris-rich ice beds, or the highly foliated unit of Shaw (1977[a]). This differential deformation may be visualized as a form of shear where plastic strain rather than brittle strain occurs (Baker, 1986). However, evidence of fault-type displacement (Ward, 1952; Shaw, 1977[a]; Boulton, 1970) indicates that brittle strain or at least a very narrow zone of plastic dislocation does occur, although this type of displacement will account for only a very small fraction of the total compressional strain. The upwarped beds of "Whisky Glacier" are similar to many described in the above studies, and they contain evidence of both fault-type displacement and deformation by shear. Features suggesting fault-type displacement indicated only minor amounts of movement, and it is assumed that the bulk of the upward movement is accommodated in zones of deformation. For this reason, the term "shear zone" rather than "shear plane" is the preferred term used here.

\section{Debris entrainment}

A striking feature of "Whisky Glacier" is the volume of debris brought to the surface by the debris-laden beds. Observations have shown that polar and sub-polar glaciers frequently carry more debris than fully temperate glaciers (Boulton, 1970), while fully dry-based glaciers are apparently incapable of significant basal erosion (Holdsworth, 1974), and carry minimal basal debris loads (Chinn, 1980). The problem of large debris loads of polythermal glaciers has been addressed by Weertman (1961) and Boulton (1970), who proposed mechanisms of basal freezing to incorporate debris into the ice mass by the glacier passing from sliding on a wet base, to becoming dry-based and frozen to the bed; or by regelation around protruding obstacles in a rough bed. Lliboutry (1968) showed that cavitation was not a necessary part of this regelation process, and later Boulton (1970) supported the regelation theory and added that movement from wet-based to dry-based states enhances plucking of the bed, and is the reason that some polar glaciers may carry more sediment than temperate glaciers. Hutter and Olunloyo (1981) have demonstrated that abrupt changes in thermal conditions at the base of a glacier, as it passes through the $0^{\circ} \mathrm{C}$ isotherm (from wet- to dry-based), cause high stress concentrations sufficiently pronounced to account for the removal of basal rock by plucking. The location of the $0^{\circ} \mathrm{C}$ isotherm is most unlikely to remain stationary and will vary with mass balance, climate changes, and other factors. An oscillating freezing front will permit blocks and large volumes of sediment to be picked up and entrained into the glacier, along with the existing basal sediment load (Boulton, 1979; Menzies, 1981). A similar mechanism has been proposed by Röthlisberger (1981), which is consistent with the sequence of white ice/ debris-rich ice/blue ice seen in sections of the shear-zone ridges at the surface of "Whisky Glacier".

In general, cold glaciers which are dry-based throughout their entire length are capable of practically no erosion (Holdsworth, 1974), while the erosion and sediment transport capabilities of fully wet-based temperate glaciers are well known. Lying between these two types of glacier are certain polythermal glaciers which are capable of extensive erosion by plucking about the basal freezing front (Boulton, 1979). The large volume of debris carried by "Whisky Glacier" suggests that it is a polythermal glacier engaged in effectively eroding its poorly lithified bed.

\section{Upwarping of sediment beds}

Although the precise nature of debris entrainment is still conjectural, it is generally agreed that entrained debris may be brought to the glacier surface by the upward movement of ice against a wedge of obstructing ice at the glacier margin (Hooke, 1968; Hudleston, 1976). The mechanisms responsible for upwarping have received considerable attention (Hooke, 1968, 1970, 1973[a]; Boulton, 1970). Observations have shown that deceleration and compression of ice occurs at the glacier margin, with increasing upwardflow vectors towards obstructing marginal ice or snow wedges. The upwarping and formation of inner moraines is confined to shallow ice near the margins of cold or polythermal glaciers with dry-based margins. Basal sliding prevents the margins of temperate wet-based glaciers from offering an effective obstruction to flow. In a study of the cold ice of Meserve Glacier, Holdsworth (1969) recognized a 


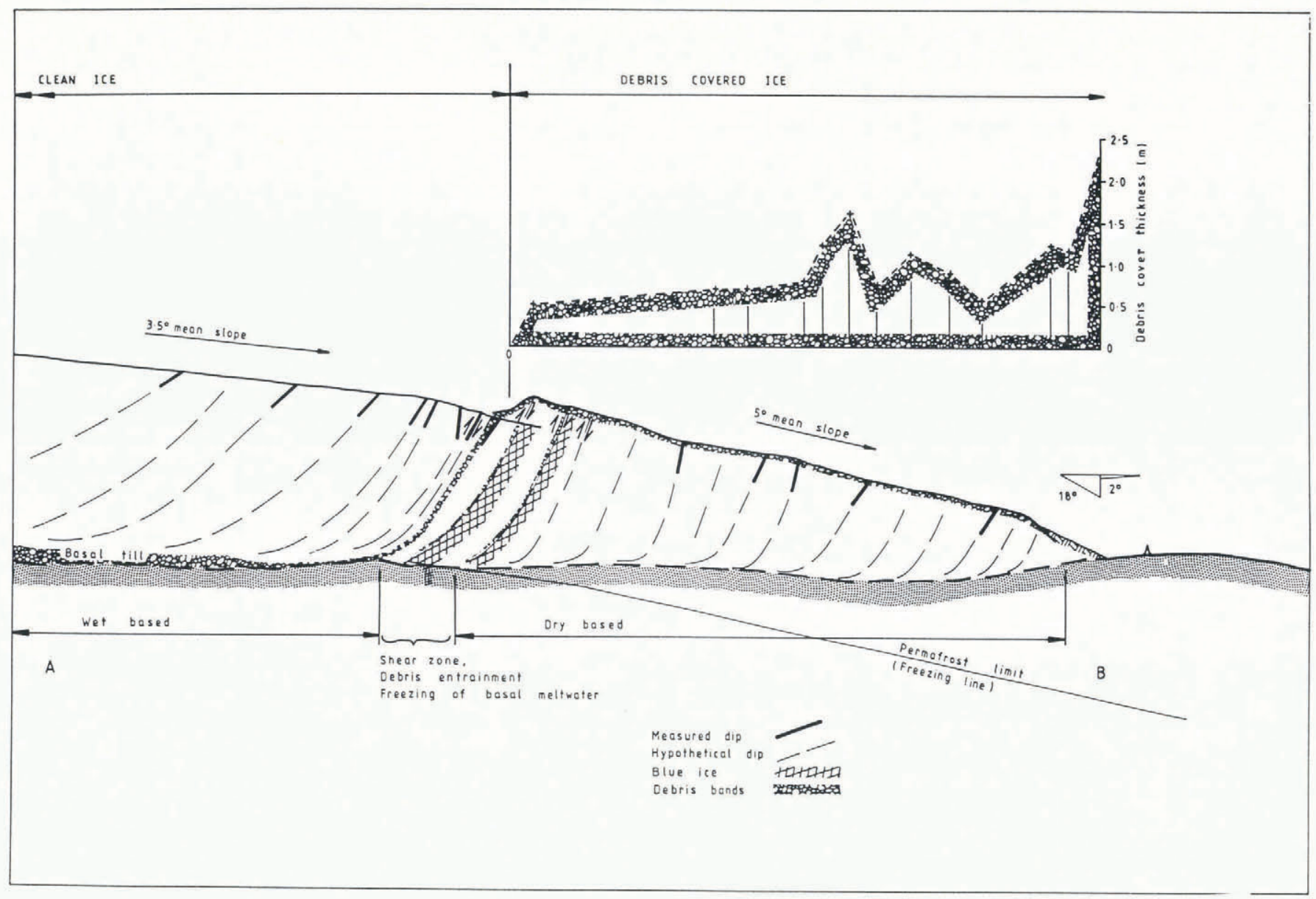

Fig. 10. Longitudinal section from white ice to the glacier snout, showing interpretation of surface features studied.

number of rheological zones within the glacier trunk which included a semi-rigid uppermost layer approximately $20 \mathrm{~m}$ in thickness overlying semi-plastic and plastic layers. Where the semi-rigid layer becomes grounded near the glacier front, it presents an increased obstruction to glacier flow. The thickness of this zone is expressed by the height of the frontal ice cliff, where this occurs. One of the authors (T.J.C.) has measured a number of ice-cliff heights in the Dry Valleys region, Antarctica, where heights, reflecting the thickness of the semi-rigid zone, vary from 20 to $45 \mathrm{~m}$. Although few ice-depth measurements have been made at inner moraines, ice thicknesses where the inner moraine appears at the surface have been estimated from data presented by Swinzow (1962): $30 \mathrm{~m}$; Goldthwait (1951), profile C: $30 \mathrm{~m}$, profile D: $36 \mathrm{~m}$, profile E: $45 \mathrm{~m}$, profile $\mathrm{F}$ : $45 \mathrm{~m}$; and Hooke (1973[b]): $25 \mathrm{~m}$.

These values are of a range similar to the measured ice-cliff heights, but are somewhat greater than the $20 \mathrm{~m}$ thickness for the semi-rigid zone given by Holdsworth (1969). The results imply that the obstruction caused by grounding of the semi-rigid zone causes the upwarping of the debris-rich beds, and that this occurs when the ice at the margin thins to $30-40 \mathrm{~m}$. At this thickness the preferred path of ice flow is to follow an upward vector rather than to move the thinner, but stiffer, wind-drifted snow wedge or debris-covered ice forming an obstruction at the glacier front. It follows that the shear zones of "Whisky Glacier", being at the position of an inner moraine, will have an ice thickness of $30-40 \mathrm{~m}$ and that the whole of the rock-glacier zone represents the obstructing shallow marginal ice, and may be predicted to be $30 \mathrm{~m}$ or less in thickness.

\section{Surface slope}

The debris-free ice area has an average surface slope of $3.5^{\circ}$, which changes at the shear zone to an average slope of $5^{\circ}$ over the rock-glacier zone. This increase in gradient across the shear zones implies a change in basal shear stress, which supports the theory of a change from wet- to dry-based conditions at this position. Down-glacier of this change, the rock-glacier zone behaves as an obstruction which effectively ponds the upper glacier and promotes upwarping of ice at the junction of the two zones. Accompanying this gradient change is a deceleration rather than an acceleration of ice, which is normally associated with a steepening surface gradient.

\section{Blue-ice beds}

It is proposed that "Whisky Glacier" is wet-based in its upper area and changes to a dry-based glacier at the shear zones. The wet-based part, which flows over poorly indurated Cretaceous sediments, is surrounded by dry-based ice which prevents basal melt water from escaping the system, except perhaps by ground-water percolation (Boulton, 1975; Menzies, 1981). At the shear zones, it is proposed that the glacier passes through the pressure melting-point surface (Fig. 10) and continues as a dry-based rock glacier. This proposed condition, where the intersection of the pressure melting-point surface with the glacier sole is coincident with the grounding of the upper "semi-rigid" zone of ice, is perhaps the most significant feature of "Whisky Glacier", and is responsible for its unusual configuration. This condition permits debris entrainment, upwarping of basal beds, and the formation of beds of regelation ice (Figs 10 and 11), to occur together at the one area on the glacier sole.

Melt water generated under the wet-based section will move down-glacier to the point where the glacier sole crosses the freezing plane, where it will refreeze. Here, accumulated melt water will be continuously frozen to the glacier sole in a cavity below the uplifting basal ice and till (Fig. 10). Souchez and Tison (1981) described a similar process for the formation of regelation ice, but in this case the beds were only a few centimeters thick. However, where the basal ice changes direction to ascend the shear zone, 


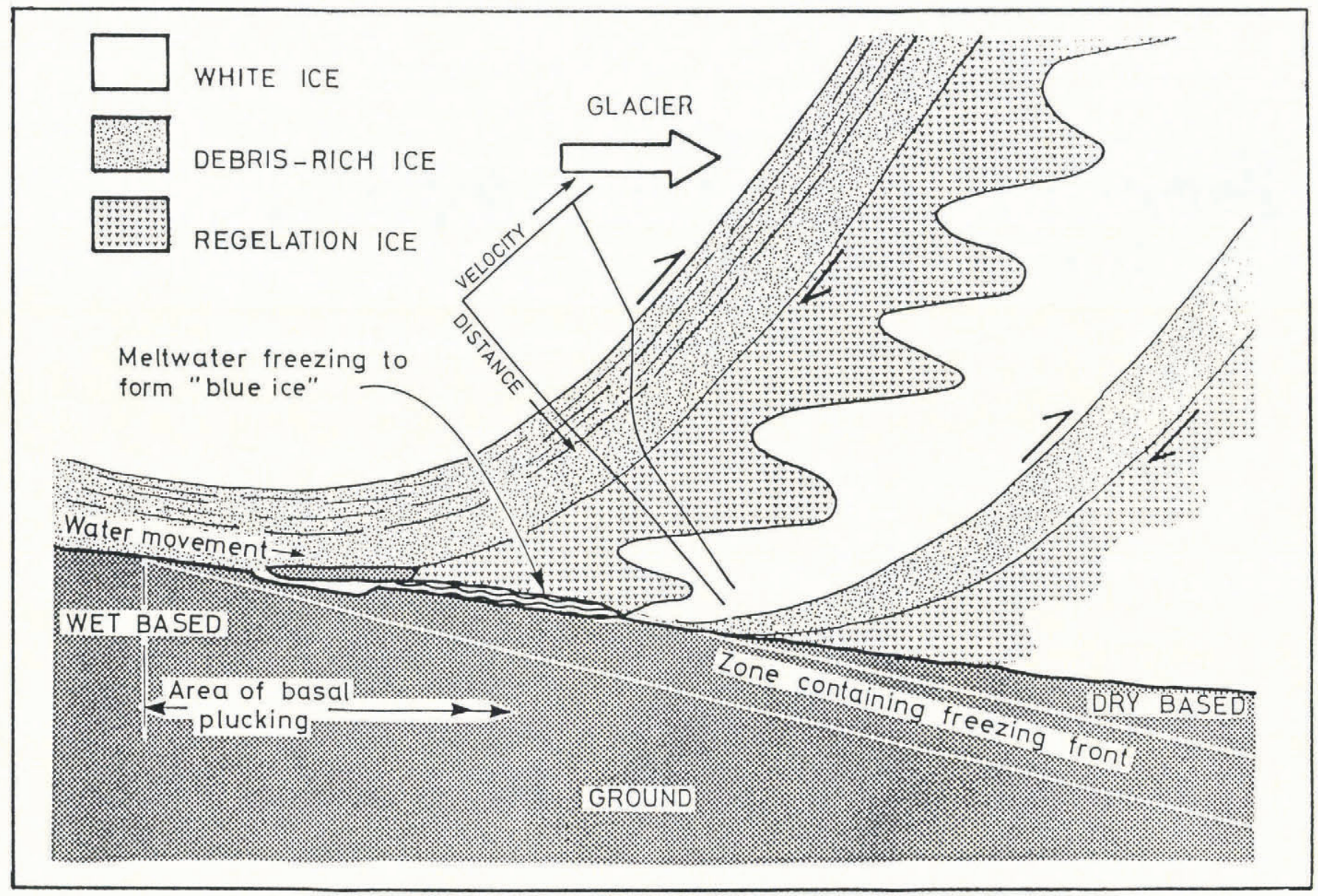

Fig. 11. Hypothetical diagram of upwarping of debris-rich beds and formation of blue-ice beds, with a suggested distribution of ice velocity with distance.

water-filled cavities may form easily, and with continuous movement and continuous freezing become a semi-permanent feature. By this process, a moving narrow, planar cavity (Fig. 11) can continuously generate the thick beds of blue, bubble-free regelation ice seen at the glacier surface (Fig. 12 ), and it is not necessary to postulate a "subglacial lake" for its formation.

\section{Topography of the shear-zone ridges}

It is tempting to attribute the topography of the concentric ridges over the debris-laden beds (Figs 7 and 8) to differential shear movement. However, since ablation rates vary considerably across this zone, from the lowest rates

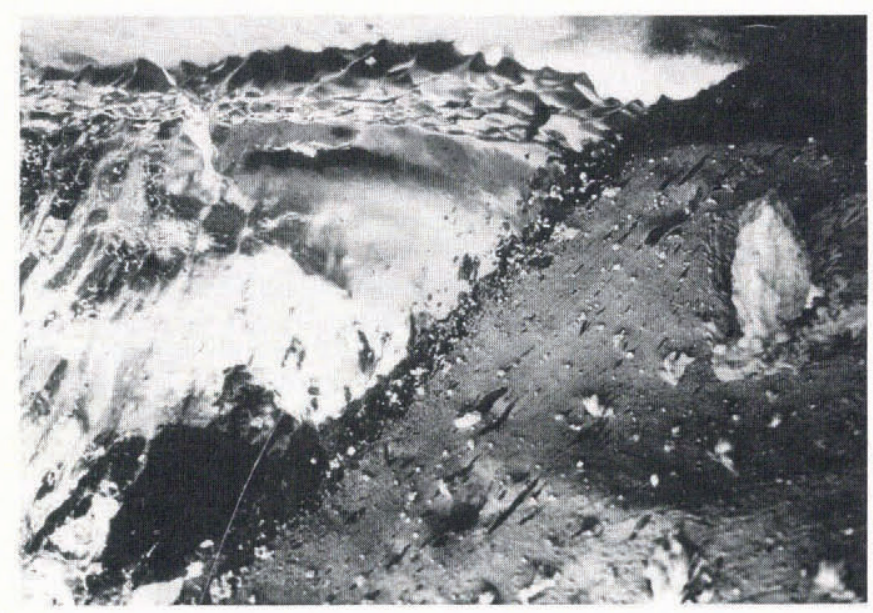

Fig. 12. Clear blue regelation ice underlying the massive debris-rich bed. Section displayed to the left of the ice-axe in Figure 8. Distance across view approximately $1 \mathrm{~m}$. under thickest debris cover to an average rate over the high-albedo clear-ice area, and highest rates under a thin debris cover (Hooke, 1970; Shaw, 1981), the topography may be dominantly ablation-controlled. Variations of thickness of debris cover across the ridges (Figs 7 and 8 ) indicate the relative rates of ablation. Figures 7 and 8 show that the debris cover is thickest over the ridge crests, which suggests that the ridges are ablation-controlled features rather than the product of shear movement. With time, proceeding down-glacier, gravitational movement and redeposition of this cover have permitted ablation to subdue the heights of these ridges. No ridges were observed with a thin debris cover over the crest which would suggest their formation by differential movement of shear zones. Downglacier of the ridges, the surface is unusually level and shows few structural or ablation features. Normally, this type of terrain develops a thermokarst topography, and the reasons why the relatively flat surface of "Whisky Glacier" has developed are not known.

\section{An alternative hypothesis}

The unusual morphology of "Whisky Glacier" may be explained by alternative hypotheses. One possibility is that it is a displaced rock glacier. During the Holocene, "Whisky Glacier" may have retreated to become a small cirque glacier below the headwalls (Fig. 2), where a readily available supply of rock material can form a rock glacier. A climate change towards glacial expansion would re-form a nevé and the rejuvenated "Whisky Glacier" would thicken and advance, displacing the rock glacier ahead to give the present glacier complex. In this case, the clear blue ice would represent coarse crystalline old ice. This explanation is thought to be unlikely, because of the lack of both surface and internal deformation consistent with a rock glacier, rather than over-ridden, being displaced by compressional flow to a new position. Also, further ice-cored moraine masses, which have locations and forms more consistent with the mechanism proposed than those of displaced rock 
glaciers, occur in the general area. These features occur at the margin of the glacier on the opposite side of the valley from "Whisky Glacier" (glacier No. IJR.38; Rabassa and others, 1982), and at the lateral margin of glacier No. IV.29 on Vega Island. Ice-cored moraines of both of these glaciers have features similar to those of "Whisky Glacier", but are not as extensively developed.

\section{CONCLUSION}

Debris forming the unusually broad zone of debris-covered ice surrounding the tongue of "Whisky Glacier" is probably supplied by a change from wet- to dry-based conditions where the glacier sole rests on poorly indurated sediments. Entrained basal debris is upwarped to the glacier surface in debris-rich beds which form part of a repeated down-glacier sequence of white ice, debris-rich ice, and clear blue ice. The upwarping of these sequences of beds occurs where the upper $30-40 \mathrm{~m}$ thick "semi-rigid" surface layer of ice becomes grounded and presents a stiff obstruction to flow. The debris-covered zone continues for a further $1 \mathrm{~km}$ at, or less than, this thickness. Melt water from the wet-based part of the glacier is trapped subglacially by the surrounding dry-based glacier sole and refreezes at the freezing front. The position of the freezing front is close to, or coincides with, the position where the "semi-rigid" layer becomes grounded. Here, the melt water continuously freezes to the glacier sole, immediately downstream of basal debris-rich ice beds, and is uplifted towards the glacier surface as beds of clear, bubble-free, blue ice.

\section{ACKNOWLEDGEMENTS}

This study was supported by Instituto Antártico Argentino and our involvement was made possible by arrangements kindly made by Ing. P. Skvarca and $\mathrm{Dr} \mathbf{J}$. Rabassa. All aerial support was provided by Fuerza Aérea Argentina who also supplied base facilities at Base Aérea Vicecomodoro Marambio. We wish to thank the other two members of our field party, F. Piccolella and L. Bertani, for their companionship and assistance, and $\mathrm{Dr} \mathrm{M}$. McSaveney and Miss B. Vaile for helpful criticisms of the manuscript.

\section{REFERENCES}

Aristarain, A.J., and Delmas, R. 1981. First glaciological studies on the James Ross Island ice cap, Antarctic Peninsula. Journal of Glaciology, Vol. 27, No. 97, p. 371-79.

Baker, R.W. 1986. The role of debris-rich ice in flow near the margins of glaciers. (Abstract.) Annals of Glaciology, Vol. 8, p. 201.

Bibby, J.S. 1966. The stratigraphy of part of north-east Graham Land and the James Ross Island group. British Antarctic Survey. Scientific Report, No. 53.

Bishop, B.C. 1957. Shear moraines in the Thule area, northwest Greenland. Snow, Ice and Permafrost Research Establishment. Research Report 17.

Boulton, G.S. 1970. On the origin and transport of englacial debris in Svalbard glaciers. Journal of Glaciology, Vol. 9, No. 56, p. 213-29.

Boulton, G.S. 1975. Processes and patterns of subglacial sedimentation: a theoretical approach. (In Wright, A.E., and Moseley, F., eds. Ice ages ancient and modern. Liverpool, Seel House Press, p. 7-42. (Geological Journal. Special Issue No. 6.))

Boulton, G.S. 1979. Processes of glacier erosion on different substrata. Journal of Glaciology, Vol. 23, No. 89, p. $15-38$.

Colman, S.M., and Pierce, K.L. 1981. Weathering rinds on andesitic and basaltic stones as a Quaternary age indicator, western United States. U.S. Geological Survey. Professional Paper 1210.

Chinn, T.J. 1980. Glacier balances in the Dry Valleys area, Victoria Land, Antarctica. [Union Géodésique et Géophysique Internationale. Association Internationale des
Sciences Hydrologiques. Commission des Neiges et Glaces.] Atelier Inventaire Mondial des Glaciers. Actes de l'Atelier de Riederalp, Suisse, 17-22 septembre 1978, p. 237-47. (IAHS-AISH Publication No. 126.)

Chinn, T.J. 1981[a]. Hydrology and climate in the Ross Sea area. Journal of the Royal Society of New Zealand, Vol. 11 , No. 4 , p. $337-86$.

Chinn, T.J. 1981[b]. Use of rock weathering-rind thickness for Holocene absolute age-dating in New Zealand. Arctic and Alpine Research, Vol. 13, No. 1, p. 33-45.

Chinn, T.J., and Maze, I. 1983. Hydrology and glaciology, Dry Valleys, Antarctica. Annual Research Report for 1980-81. Christchurch, Ministry of Works and Development. (Report No. WS 900.)

Goldthwait, R.P. 1951. Development of end moraines in east-central Baffin Island. Journal of Geology, Vol. 59, No. 6 , p. $567-77$.

Goldthwait, R.P. 1960. Study of ice cliff in Nunatarssuaq, Greenland. U.S. Army Cold Regions Research and Engineering Laboratory. Technical Report 39.

Hambrey, M.J. 1976. Structure of the glacier Charles Rabots Bre, Norway. Geological Society of America. Bulletin, Vol. 87, No. 11, p. 1629-37.

Holdsworth, G. 1969. Structural glaciology of Meserve Glacier. Antarctic Journal of the United States, Vol. 4, No. 4 , p. $126-28$.

Holdsworth, G. 1974. Meserve Glacier, Wright Valley, Antarctica: Part I. Basal processes. Ohio State University. Institute of Polar Studies. Report No. 37.

Hollin, J.T., and Cameron, R.L. 1961. I.G.Y. glaciological work at Wilkes Station, Antarctica. Journal of Glaciology, Vol. 3, No. 29, p. 833-42.

Hooke, R. LeB. 1968. Correspondence. Comments on "The formation of shear moraines: an example from south Victoria Land, Antarctica. Journal of Glaciology, Vol. 7, No. 50 , p. $351-52$

Hooke, R. LeB. 1970. Morphology of the ice-sheet margin near Thule, Greenland. Journal of Glaciology, Vol. 9, No. 57 , p. 303-24.

Hooke, R. LeB. 1973[a]. Flow near the margin of the Barnes ice cap, and development of ice-cored moraines. Geological Society of America. Bulletin, Vol. 84, No. 12, p. 3929-48.

Hooke, R. LeB. 1973[b]. Structure and flow in the margin of the Barnes ice cap, Baffin Island, N.W.T., Canada. Journal of Glaciology, Vol. 12, No. 66, p. 423-38

Hooke, R. LeB., and Hudleston, P.J. 1978. Origin of foliation in glaciers. Journal of Glaciology, Vol. 20, No. 83 , p. $285-99$

Hooke, R. LeB., and others. 1972. Creep of ice containing dispersed fine sand, by R. LeB. Hooke, B.B. Dahlin, and M.T. Kauper. Journal of Glaciology, Vol. 11, No. 63, p. 327-36.

Hudleston, P.J. 1976. Recumbent folding in the base of the Barnes ice cap, Baffin Island, Northwest Territories, Canada. Geological Society of America. Bulletin, Vol. 87, No. 12 , p. $1684-92$.

Hutter, K., and Olunloyo, V.O.S. 1981. Basal stress concentrations due to abrupt changes in boundary conditions: a cause for high till concentration at the bottom of a glacier. Annals of Glaciology, Vol. 2, p. 29-33.

Lliboutry, L. 1968. General theory of subglacial cavitation and the sliding of temperate glaciers. Journal of Glaciology, Vol. 7, No. 49, p. 21-58.

Menzies, J. 1981. Freezing fronts and their possible influence upon processes of subglacial erosion and deposition. Annals of Glaciology, Vol. 2, p. 52-56.

Rabassa, J. 1982. Estratigrafía de los depositos glacigenicos en el sector norte de la Isla James Ross, Península Antártica, Argentina. Quinto Congreso Latinoamericano de Geología, Argentina. ACTAS, IV, p. 237-51.

Rabassa, J., and others. 1982. Glacier inventory of James Ross and Vega islands, Antarctic Peninsula, by J. Rabassa, P. Skvarca, L. Bertani, and E. Mazzoni. Annals of Glaciology, Vol. 3, p. 260-64.

Rains, R.B., and Shaw, J. 1981. Some mechanisms of controlled moraine development, Antarctica. Journal of Glaciology, Vol. 27, No. 95, p. 113-28. 
Röthlisberger, H. 1981. General discussion. Glacier bed erosion, erosion features, and processes at the terminus. Annals of Glaciology, Vol. 2, p. 187.

Shaw, J. 1977[a]. Till body morphology and structure related to glacier flow. Boreas, Vol. 6, No. 2, p. 189-201.

Shaw, J. 1977[b]. Tills deposited in arid polar environments. Canadian Journal of Earth Sciences, Vol. 14, No. 6, p. 1239-45.

Souchez, R.A. 1967. The formation of shear moraines: an example from south Victoria Land, Antarctica. Journal of Glaciology, Vol. 6, No. 48, p. 837-43.

Souchez, R.A. 1971. Ice-cored moraines in south-western Ellesmere Island, N.W.T., Canada. Journal of Glaciology, Vol. 10, No. 59, p. 245-54.
Souchez, R.A., and Tison, J.-L. 1981. Basal freezing of squeezed water: its influence on glacier erosion. Annals of Glaciology, Vol. 2, p. 63-66.

Swinzow, G.K. 1962. Investigation of shear zones in the ice sheet margin, Thule area, Greenland. Journal of Glaciology, Vol. 4, No. 32, p. 215-29.

Toebes, C. 1963. Applied hydrology. Vol. I. Wellington, New Zealand Department of Education. Technical Correspondence School.

Ward, W.H. 1952. The glaciological studies of the Baffin Island Expedition, 1950. Part II: The physics of deglaciation in central Baffin Island. Journal of Glaciology, Vol. 2, No. 11, p. 9-22.

Weertman, J. 1961. Mechanism for the formation of inner moraines found near the edge of cold ice caps and ice sheets. Journal of Glaciology, Vol. 3, No. 30, p. 965-78. 